\title{
Highest Composition Dissimilarity among Phytoplankton Communities at Intermediate Environmental Distances across High-Altitude Tropical Lakes
}

\author{
Alonso Cartuche ${ }^{1,2}$, Kalina M. Manoylov ${ }^{3, *(D)}$, Bastiaan W. Ibelings ${ }^{1}$ and Patrick Venail ${ }^{1,4}$ (D) \\ 1 Microbial Ecology Group, Department F.-A. Forel for Environmental and Aquatic Sciences and Institute for \\ Environmental Sciences, University of Geneva, 66 Boulevard Carl Vogt, 1205 Geneva, Switzerland; \\ victor.cartuche@unl.edu.ec (A.C.); Bastiaan.Ibelings@unige.ch (B.W.I.); pvenail@utec.edu.pe (P.V.) \\ 2 Ingeniería Ambiental, Universidad Nacional de Loja, Ciudad Universitaria Guillermo Falconí, \\ Loja 110150, Ecuador \\ 3 Department of Biological and Environmental Sciences, Georgia College and State University, \\ Milledgeville, GA 31061, USA \\ 4 Centro de Investigación y Tecnología del Agua-CITA, Departamento de Ingeniería Ambiental, \\ Universidad de Ingeniería y Tecnología-UTEC, Lima 15063, Peru \\ * Correspondence: kalina.manoylov@gcsu.edu
}

\section{check for} updates

Citation: Cartuche, A.; Manoylov, K.M.; Ibelings, B.W.; Venail, P. Highest Composition Dissimilarity among Phytoplankton Communities at Intermediate Environmental Distances across High-Altitude Tropical Lakes. Water 2021, 13, 1378. https://doi.org/10.3390/w13101378

\section{Academic Editors: Émilie}

Saulnier-Talbot, Isabelle Lavoie and Philippe Archambault

Received: 16 April 2021

Accepted: 11 May 2021

Published: 15 May 2021

Publisher's Note: MDPI stays neutral with regard to jurisdictional claims in published maps and institutional affiliations.

Copyright: (c) 2021 by the authors. Licensee MDPI, Basel, Switzerland. This article is an open access article distributed under the terms and conditions of the Creative Commons Attribution (CC BY) license (https:// creativecommons.org/licenses/by/ $4.0 /)$.

\begin{abstract}
Tropical high-altitude lakes are vital freshwater ecosystems for the functioning and dynamics of tropical high-altitude wetlands called páramos, found at over $3300 \mathrm{~m}$ above sea level. They play a major role in the hydrogeological cycle and provide important hydrological services such as water storage, and yet they are understudied. Describing the patterns and processes of community composition in these lakes is required to better understand the consequences of their degradation by human activities. In this study we tested the geographical and environmental components of distance-decay relationships in the phytoplankton structure across 24 tropical high-altitude lakes from Southern Ecuador. Phytoplankton composition at the phyla level showed high among-lake variation in the tropical high-altitude lakes from Tres Lagunas. We found no links, however, between the geographic distance and phytoplankton composition. On the contrary, we observed some environmentally related patterns of community structure like redox potential, altitude, water temperature, and total phosphorus. The absence of support for the distance-decay relationship observed here can result from a conjunction of local niche-based effects and dispersal limitations. Phytoplankton community composition in the Tres Lagunas system or any other ecosystem may be jointly regulated by niche-based and neutral forces that still need to be explored. Despite not proving a mechanistic explanation for the observed patterns of community structure, we hope our findings provide understanding of these vulnerable and vital ecosystems. More studies in tropical high-altitude lakes are urgently required.
\end{abstract}

Keywords: community composition; dissimilarity; distance-decay; páramos; phytoplankton; tropical high-altitude lakes; wetlands

\section{Introduction}

Defining the processes that determine the patterns of community structure is a major challenge in ecology [1]. For decades, community ecologists have generated numerous hypotheses regarding the distribution and coexistence of species within and amongst habitats [2,3]. In this context, the distance-decay relationship suggests that similarity amongst ecological communities decreases with geographical distance, meaning that geographically distant communities are expected to be more dissimilar in their structure and composition than closer ones [4,5]. That pattern can be linked to at least two nonexclusive mechanisms. First, communities become less similar with distance because the environmental conditions become less similar. This assumes a strong correlation between 
geographic distance and environmental dissimilarity. In community ecology, this nichebased process is also called "species sorting" [6]. Second, the dispersal capacity of living organisms is limited. This means that even if the environment does not change over space, the limited capacity of an organism to disperse does not allow it to succeed everywhere. Thus, an organism is more likely to be found closer to its original localization [7]. Dispersal limitation is a key factor explaining species distribution under a neutral view, which considers that organisms perform equally in any environmental conditions. Both forces can contribute to generate a distance-decay pattern in community composition [8]. Therefore, a distance-decay pattern alone cannot be used as evidence of either one of the underlying mechanisms. Indeed, actual changes in community structure over space and distance may result from a balance between local niche-based processes and regional dispersal capabilities [9].

For microorganisms, a niche-based perspective called the Baas-Becking hypothesis dominated the literature for decades $[10,11]$. It suggests that given their small size, microorganisms are ubiquitous, but the local environment determines where they can persist. This means that only the capacity of a microorganism to cope with the different local environmental conditions, not its dispersal capabilities, would determine its spatial distribution patterns. Consequently, distance-decay relationships in microorganisms may result from a strong correlation between geographic and environmental distance, where species sorting would be the dominant underlying mechanism. However, evidence collected over the last two decades suggests that microorganisms show biogeographical patterns, with both local (e.g., species sorting) and regional (e.g., dispersal) processes being important [12-17]. As with macro-organisms, the distance-decay relationships in microorganisms are jointly influenced by local environmental filters and dispersal $[5,18,19]$.

In microalgae, the evidence for local and regional processes dominating community structure is mixed [14,18-23]. A study with diatoms from Finnish streams found limited support for species sorting. Additionally, spatial effects overcame environmental variables as drivers of community structure [14]. On the contrary, algal communities in lakes and reservoirs from Greece showed a strong correlation with environmental conditions [19]. Similarly, community structure had stronger control through niche-related rather than spatial factors amongst diatom communities in another study in Finland [18]. Two other studies showed that algal community structure was controlled simultaneously by both spatial and environmental factors $[20,21]$. Regarding the relationship between geographical distances and community similarity in microalgae, some studies found evidence of distancedecay relationships $[18,21,23]$, but some others did not [19]. Such discrepancies can be explained because factors such as the spatial scale or the environmental context influence the distance-decay relationship in microalgae [20,22].

The freshwater ecosystems of the tropical Andes are among the most high-altitude and intensely irradiated environments in the world, and although it is one of the most biodiverse regions on the planet, knowledge of its biodiversity is scarce and fragmented, with the exception of fish, which is the most studied group. High-altitude lakes and wetlands play important roles as flow regulators and reservoirs of water from glacier melt and rainfall, which is ultimately used by communities for consumption, irrigation, and energy production [24]. In addition, their importance lies in their function of regulating the upper river basins due to their capacity to buffer increases in flow, avalanches, and sediment transport [25].

Community ecology studies on microalgae from tropical lakes, especially at high altitudes, are rare. We know little about the patterns of distribution of microalgae in such freshwater ecosystems. The extreme environmental conditions of tropical high-altitude lakes suggest that particular algal communities well adapted to such harsh conditions might be found [26]. Thus, studies on patterns and processes of community composition in high altitude ecosystems are required to better understand the consequences of their degradation by human activities, including climate change. In this study, we tested the geographical and environmental components of the distance-decay relationships in the 
phytoplankton structure across 24 tropical high-altitude lakes from Southern Ecuador. We hope our findings will help improve our comprehension of these vulnerable and vital ecosystems.

\section{Materials and Methods}

\subsection{Studied Lakes}

The Tres Lagunas system is a group of shallow, tropical high-altitude lakes located in Southern Ecuador at an average altitude of $3323 \mathrm{~m}$ above sea level (Figure 1). For this study, we included 24 lakes with wide ranges of physicochemical and biotic characteristics (Table 1, Table S1 in supplementary material) separated by around one hundred meters to up to six kilometers from each other [27].

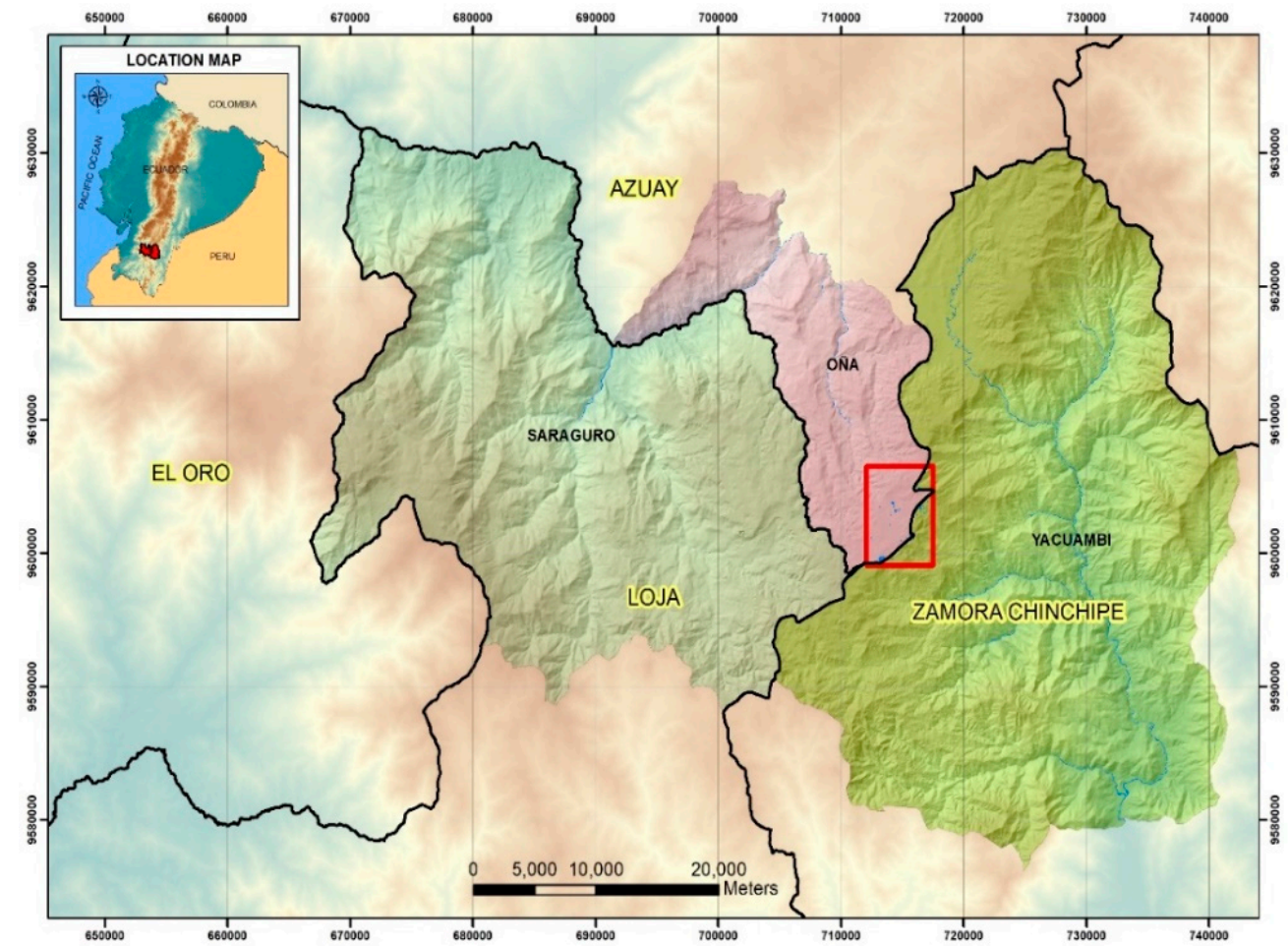

Figure 1. Location of the Tres Lagunas lake system in Southern Ecuadorian Andes around 3300 m.a.s.1.

\subsection{Sampling and Physicochemical Analyses}

We collected data on chlorophyll-a concentration $\left(\mathrm{mg} \mathrm{L}^{-1}\right)$ using a bbe Moldaenke fluoroprobe. Dissolved oxygen $\left(\mathrm{mg} \mathrm{L}^{-1}\right)$, redox potential $(\mathrm{mv})$, conductivity $(\mu \mathrm{S} / \mathrm{cm}), \mathrm{pH}$, and water temperature $\left({ }^{\circ} \mathrm{C}\right)$ were measured using a portable multiparameter probe HQ40D Hach. All variables were measured once at $0.5 \mathrm{~m}$ below the surface as close as possible to the center of each lake. For nutrient analysis we used acid washed $10 \mathrm{~mL}$ plastic tubes to collect water samples $(\sim 9.5 \mathrm{~mL})$ at $0.50 \mathrm{~m}$ below surface and as far from shore to avoid shallow waters. We preserved the water samples with $98 \%$ sulfuric acid. All samples were immediately stored in the dark and cold conditions, brought to Loja (Ecuador), and then to Geneva (Switzerland) by plane. Sampling was performed from 8 to 11 November 2016. Total phosphorus $\left(\mu \mathrm{g} \mathrm{L}^{-1}\right)$ and nitrites/nitrates $\left(\mu \mathrm{g} \mathrm{L}^{-1}\right)$ measurements were performed on an AQ2 discrete analyzer based on EPA (Environmental Protection Agency) 365.1 method version 2 (based on reactions specific for the orthophosphate ion and semi-automated colorimetry) and EPA 353.2 version 2 method (based on reactions specific for nitrates and automated colorimetry), respectively. 
Table 1. Overview of the geographic, physicochemical, and biological variables measured along the 24 lakes included in the study.

\begin{tabular}{|c|c|c|c|}
\hline Variable & Minimum & Maximum & Mean \\
\hline Area (ha) & 0.51 & 12.41 & 2.01 \\
\hline Altitude (m.a.s.l.) & 3288 & 3362 & 3323 \\
\hline Maximum depth (m) & 1.4 & 8.7 & 2.9 \\
\hline Temperature $\left({ }^{\circ} \mathrm{C}\right)$ & 10.7 & 15.29 & 13.21 \\
\hline $\mathrm{pH}$ & 3.45 & 5.45 & 4.36 \\
\hline Oxygen $\left(\mathrm{mg} \mathrm{L}^{-1}\right)$ & 6.7 & 7.48 & 7.07 \\
\hline Redox (mv) & 189 & 321 & 248 \\
\hline $\begin{array}{l}\text { Conductivity } \\
\left(\mu \mathrm{cm}^{-1}\right)\end{array}$ & 23.6 & 51.4 & 36.4 \\
\hline $\begin{array}{l}\text { Total phosphorus } \\
\qquad\left(\mu \mathrm{g} \mathrm{L}^{-1}\right)\end{array}$ & 0.01 & 0.15 & 0.058 \\
\hline $\begin{array}{l}\text { Nitrates/nitrites } \\
\qquad\left(\mathrm{mg} \mathrm{L}^{-1}\right)\end{array}$ & 0.0015 & 0.0194 & 0.0080 \\
\hline Chlorophyll-a $\left(\mu \mathrm{g} \mathrm{L}^{-1}\right)$ & 1.49 & 5.05 & 3.01 \\
\hline Phytoplankton biovolume $\left(\mu \mathrm{m}^{3} \mathrm{~mL}^{-1} 10^{6}\right)$ & 3.63 & 241.67 & 32.39 \\
\hline
\end{tabular}

\subsection{Phytoplankton Composition}

For phytoplankton analysis, we collected around $90 \mathrm{~mL}$ of water in $100 \mathrm{~mL}$ acidwashed plastic bottles at $0.5 \mathrm{~m}$ below surface, as far from the shore as possible, and preserved the samples with glutaraldehyde. All samples were immediately stored in dark and cold conditions, brought to Loja (Ecuador), and then to Geneva (Switzerland) by plane. We used an inverted microscope with $400 \times x$ magnification for cell counting. Phytoplankton samples were previously concentrated by letting them settle in plastic tubes for $24 \mathrm{~h}$. For cell counting, we used a Sedgwick-Rafter chamber cell counter. Five transects of 20 fields of view (at $400 \times \mathrm{x}$ magnification) were defined in each one, and in total there were 100 fields of vision for each sample/lake. A field of vision measures $0.38 \mathrm{~mm}^{2}$. We took pictures of each field of vision, which were used later for phytoplankton identification. Microalgae biovolume analysis ( $\mathrm{mL}$ per $\mathrm{mL}$ of water) was calculated using geometric forms of microalgae and mathematical equations to get accurate cell volume [28]. Cell density readings (in cells per $\mathrm{mL}$ ) were determined as well. We established the composition of the phytoplankton community of each lake based on the prevalence of six major phyla: Chlorophyta, Cyanophyta, Bacillariophyta, Pyrrophyta, Euglenophyta, and Cryptophyta. Unidentified organisms were reported as unknown and represented less than $2 \%$ of the total abundance in every lake. The unknown algae were not included in further analyses.

\subsection{Community Dissimilarity}

We used two methods for measuring the phytoplankton community dissimilarity among lakes in terms of their algal phyla composition based on their relative contribution to total biovolume. First, we calculated the inverse Bray-Curtis community similarity index between each pair of lakes. The inverse index allowed interpreting higher values of the index as an indicator of higher dissimilarity amongst lakes in their phytoplankton community structure at the phylum level. Second, we performed a cluster analysis based on the phyla composition of lakes and then calculated the Euclidean distances separating each pair. A higher Euclidean community distance represents a higher community dissimilarity. We used JMP (SAS) software version 14.0 to perform the clustering and to estimate the community structure distances. The two measures of community similarity were highly correlated $(\rho=0.886, p<0.0001, n=276)$. For simplicity, only results based on Euclidean 
community distances are presented. Results with Bray-Curtis similarity provided almost identical results.

\subsection{Geographical Distances}

We calculated the geographical distances in meters amongst lakes using satellite images and data on latitude, longitude, and altitude from the center of each lake.

\subsection{Environmental Distances}

We included seven variables to estimate environmental distances amongst lakes: conductivity, nitrates/nitrites concentration, oxygen concentration, $\mathrm{pH}$, redox potential, water temperature, and total phosphates concentration. For this, we first performed a cluster analysis based on the physical and chemical variables and then calculated the Euclidean distances separating each pair. A higher Euclidean distance represents a higher environmental dissimilarity. We used JMP (SAS) software version 14.0 to perform the clustering and to estimate the Euclidean-based environmental distances.

\subsection{Data Analysis}

We first performed a correlation-based principal component analysis (PCA) to reveal potential links among the variables and to determine which variables explained most of the differences among lakes. The PCA included seventeen variables: two morpho-geographic (surface area of the lake and altitude), seven physical and chemical (conductivity, nitrates/nitrites, oxygen concentration, $\mathrm{pH}$, redox potential, water temperature, and total phosphorus) and eight biological variables related to phytoplankton (Chlorophyll-a, total biovolume, \%Chlorophyta, \%Bacillariophyta, \%Cyanophyta, \%Chrysophyta, \%Euglenophyta, and \%Pyrrophyta). To test the relationships between environmental, geographic, and community structure distances (dissimilarity), we fitted linear and binomial models to the data using JMP version 14.0 (SAS).

\section{Results}

\subsection{Links amongst Variables}

The principal component analysis (PCA) reported a first component positively related to chlorophyll-a that explained $23.9 \%$ of the variation in the data and a second component positively related to altitude and $\mathrm{pH}$ that explained $14.8 \%$ of the variation in the data (Figure 2). As shown by the PCA, some community structure variables (i.e., percentages of each phyla) were strongly correlated to environmental variables (Table 2). The contribution of diatoms to total biovolume (\%Bacillariophyta) decreased with the redox potential and with altitude above sea level. This means that, relatively speaking, less diatoms were observed at higher altitudes. The contribution of cyanobacteria (\%Cyanophyta) to total biovolume decreased with an increase in temperature, meaning they were more present in colder waters. Finally, the contribution of Euglenophytes (\%Euglenophyta) to total biovolume increased with total phosphorus. A strong negative correlation between the percentage of diatoms and the percentage of dinoflagellates (\%Pyrrophyta) was observed $(\rho=-0.608, p<0.001)$, which means that an increase in the relative biovolume of diatoms was at the detriment of the biovolume of dinoflagellates. No other strong correlations were observed amongst the relative contribution of each phyla to total biovolume. 


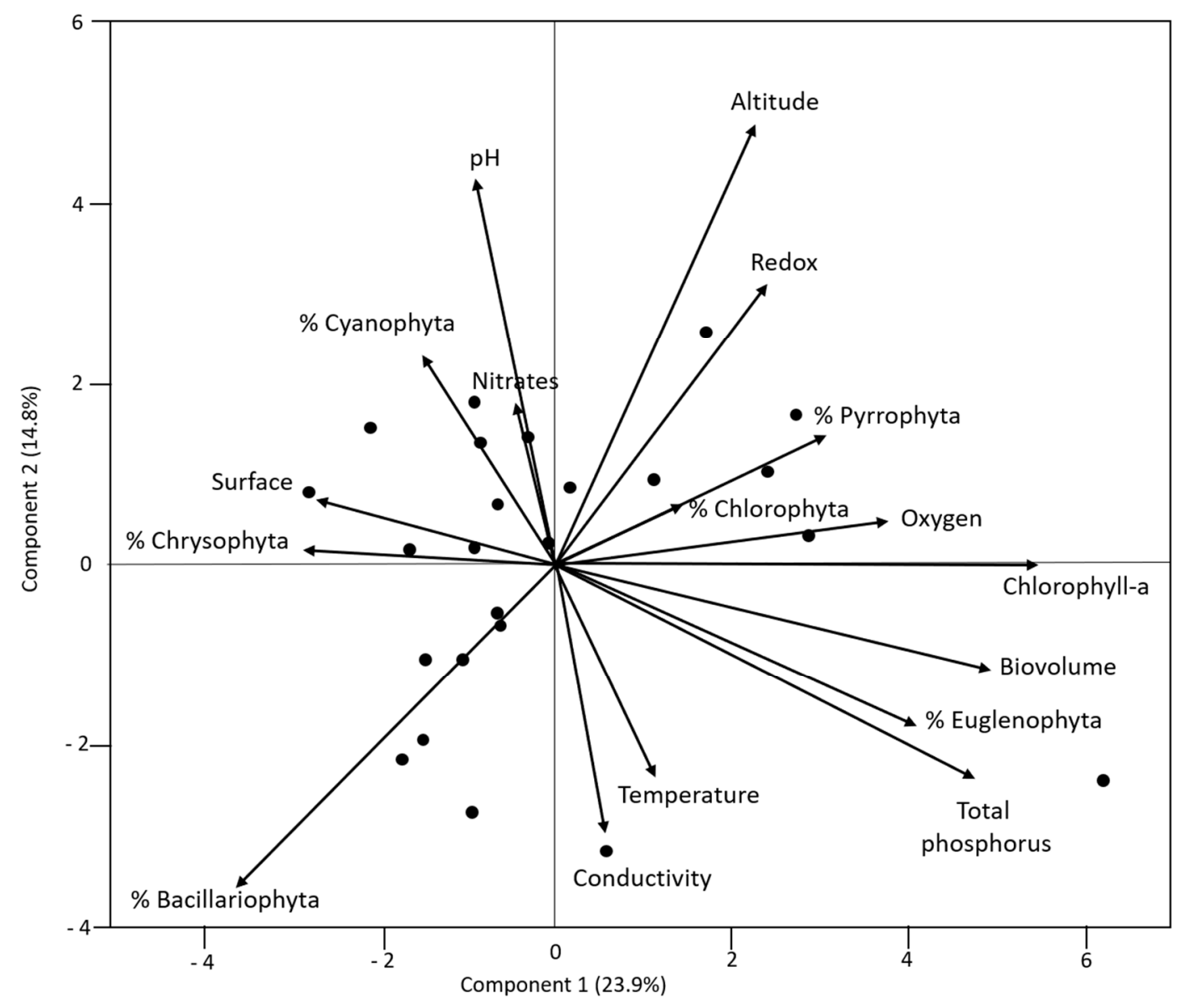

Figure 2. Principal component analysis (PCA) including seventeen variables in total: two geographic (altitude and surface), seven physical and chemical (conductivity, nitrates/nitrites, oxygen concentration, $\mathrm{pH}$, redox potential, water temperature, and total phosphorus), and eight biological variables related to phytoplankton (Chlorophyll-a, total biovolume, \%Chlorophyta, \%Bacillariophyta, \%Cyanophyta, \%Chrysophyta, \%Euglenophyta, and \%Pyrrophyta). Dots represent lakes.

Table 2. Coefficients of correlations amongst composition variables (contribution of each phyla to total biovolume) and environmental variables. Only correlation coefficients over 0.45 and with $p<0.05$ are shown.

\begin{tabular}{ccc}
\hline Structure Variable & Environmental Variable & Coefficient of Correlation \\
\hline$\%$ Bacillariophyta & Redox potential & -0.592 \\
\hline$\%$ Bacillariophyta & Altitude & -0.466 \\
\hline$\%$ Cyanophyta & Temperature & -0.466 \\
\hline$\%$ Euglenophyta & Total phosphorus & 0.452 \\
\hline
\end{tabular}

\subsection{Phyla Community Structure}

We found high variability in the phyla composition of the high-altitude tropical lakes from Southern Ecuador (Figure 3). The number of phyla (from 4 to 6) and their relative contributions to total biovolume in each lake determined their structure similarities. Some lakes were dominated by only one phylum, while others were more equally structured in terms of the contribution of the different phyla to total biovolume. This analysis revealed clusters of lakes with similarities in their phyla composition. Lake 31 was isolated in the clustering due to the higher contribution of Euglenophyta to total biovolume and almost a total absence of Cyanophyta and Chlorophyta. A cluster of four lakes (10, 12, 29, and 32) was strongly dominated by diatoms. The PCA (Figure 2) shows those lakes were located at lower altitude and had lower redox potential values. Another cluster of four lakes $(2,4,7$, 
and 9) was dominated by cyanobacteria and associated with colder water temperatures. A large cluster of seven lakes $(8,19,18,16,21,23,14)$ dominated by Pyrrophyta was revealed. Finally, a group of six lakes $(1,6,27,28,17,30)$ with no clear-cut dominance of one phylum was also depicted.
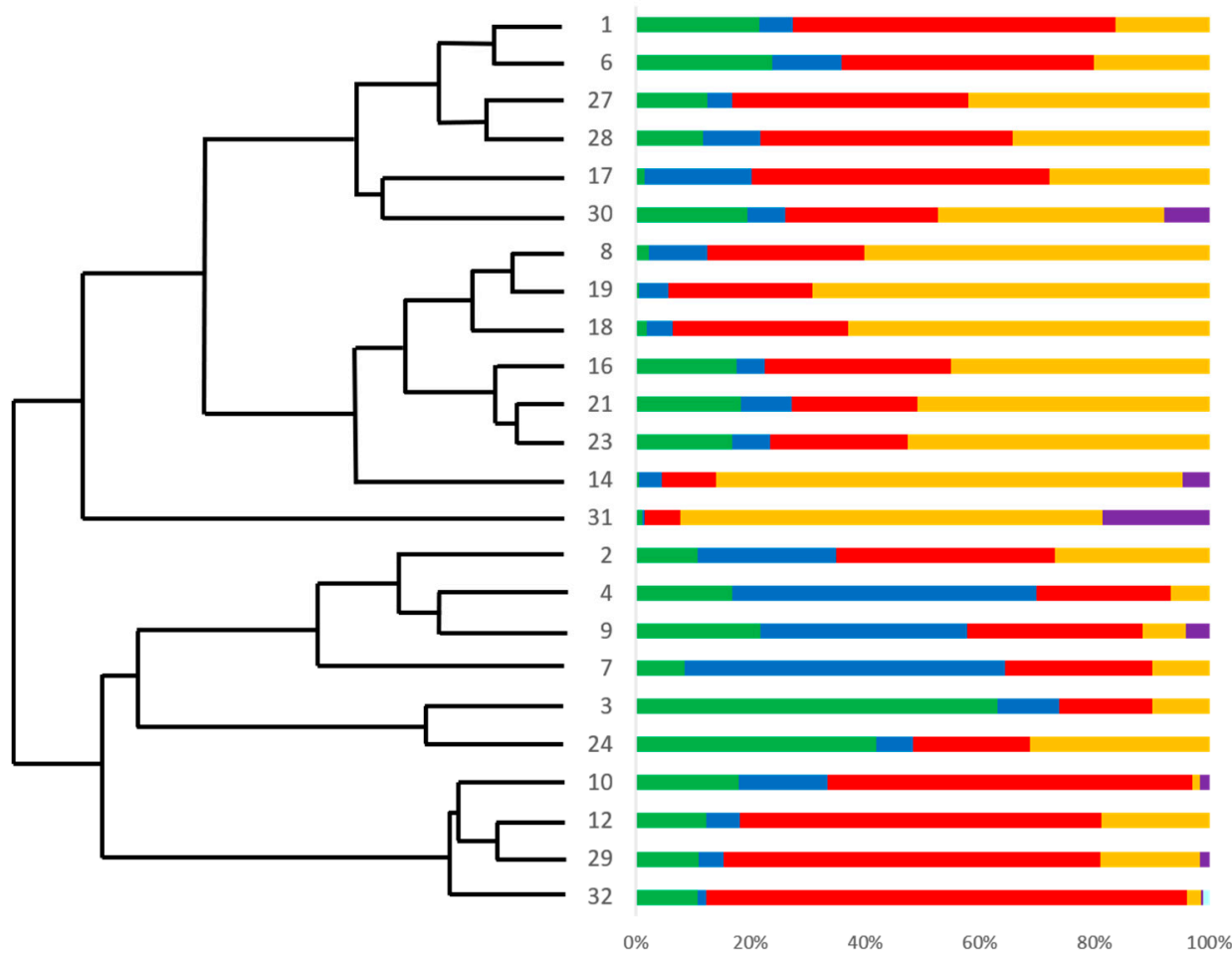

Chlorophyta

Cyanophyta

Bacillariophyta

Pyrrophyta

Euglenophyta

Cryptophyta

Figure 3. Cluster analysis of the phyla community structure of the 24 lakes. Numbers in the middle of the figure represent lake identities. The percentages represent the contribution of each phyla to total biovolume.

\subsection{Geographic Distance, Environmental Distance, and Community Similarity}

We found no evidence of a relationship between geographic distance and the composition dissimilarity (Figure $4 \mathrm{a}, \mathrm{R}^{2}=0.0048, p=0.246, n=276$ ). On the other hand, we found weak but positive linear and binomial relationships between environmental distances and composition similarity (Figure $4 b$, linear: $R^{2}=0.0162, p=0.034$; binomial: $R^{2}=0.033$, $p=0.001, n=276$ ). The binomial model explained twice the variance in community similarity compared to the linear model. The geographic and environmental distances from our dataset were not linearly related $\left(R^{2}=0.0002, p=0.81\right)$, but a binomial model provided a fit $\left(R^{2}=0.034, p=0.008\right)$. A model with environmental and geographic distance together did not provide a better fit to the data than environmental distances alone $\left(R^{2}=0.021\right.$, $p=0.0523)$. 

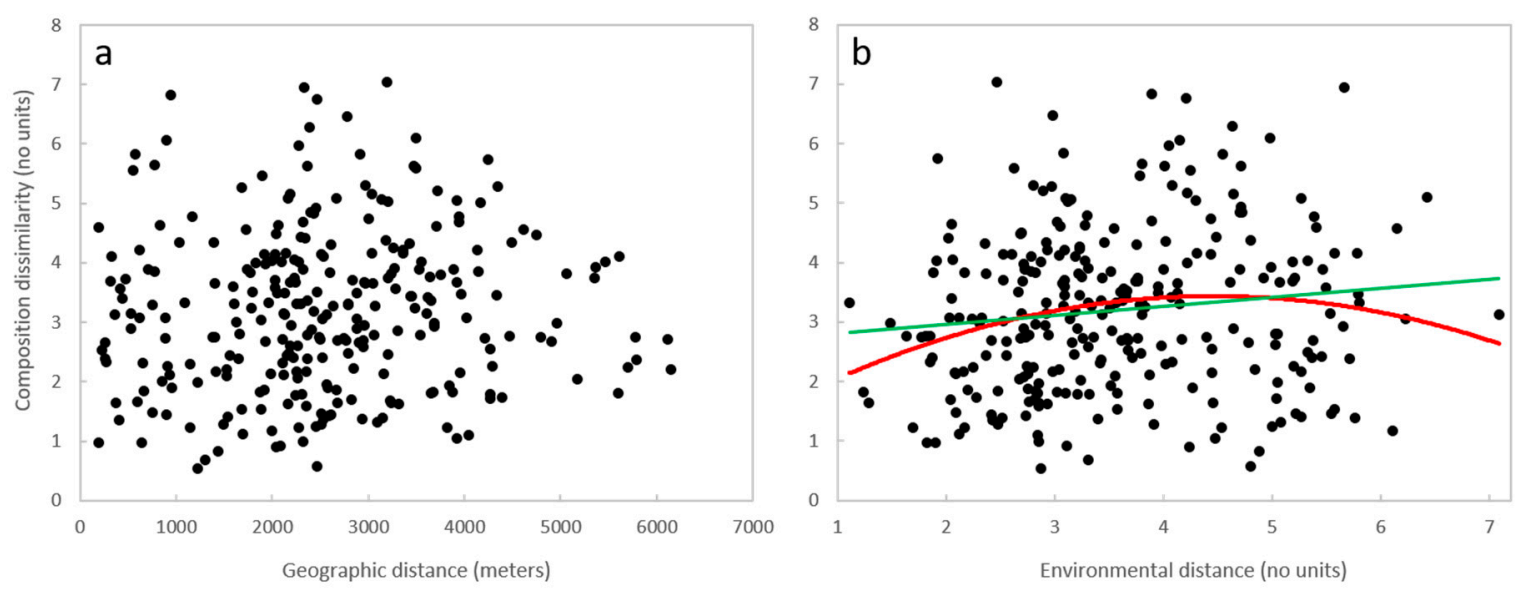

Figure 4. Relationships between geographic distance and composition dissimilarity (a), linear fit: $\mathbf{R}^{2}=0.0048, p=0.246$, $n=276)$ and between geographic distance and composition dissimilarity (b), linear fit in green: $\mathrm{R}^{2}=0.0162, p=0.034$; binomial fit in red: $\mathrm{R}^{2}=0.033, p=0.001, n=276$ ). Each point represents a pairwise lake distance (either geographic or environmental).

\section{Discussion}

The aim of the current study was to characterize the spatial structure of phytoplankton communities in tropical high-altitude lakes and to explore its relationships with geographical and environmental distances in the Tres Lagunas system. We found large among-lake variation in the structure of phytoplankton assemblages at the highest taxonomic level. The number of phyla and their relative contributions to total biovolume were spatially highly variable. Our results show that the phytoplankton composition of the lakes was more related to environmental than geographic distances. Community dissimilarity at the phyla level was greatest at intermediate environmental distances. In other words, the composition dissimilarity of phytoplankton increases from low to intermediate environmental distances but drops when the environments become more dissimilar. Previous studies with freshwater phytoplankton also found relationships between environmental distance and community dissimilarity [18-20,22]. However, these studies focused on community variation at much lower taxonomic levels (e.g., species) and reported either linear or logarithmic patterns. At the large scale of our research, a higher taxonomic level of differentiation was justified. Differences in the taxonomic resolution used may impede our results to be comparable to previous studies.

Our analyses of the influence of individual environmental variables on community composition (i.e., PCA) revealed that redox potential, altitude, water temperature, and total phosphorus were the variables that contributed most to the variability in phytoplankton structure. An increase in the redox potential and altitude above sea level (the two environmental variables were positively correlated) were detrimental for the contribution of diatoms. Phytoplankton composition can be strongly related to redox potential in freshwater ecosystems [29]. More specifically, diatom community composition and taxa distribution has been shown to be very sensitive to variations in redox potential in a peatland ecosystem [30]. It is possible that the diatoms present in the Tres Lagunas system prefer less humified conditions. The increase in temperature was unfavorable for cyanobacteria contribution whereas increasing total phosphate benefited the contribution of euglenophytes. Previous studies also reported effects of environmental variables such as $\mathrm{pH}$, conductivity, total phosphorus, and temperature on phytoplankton community composition [18,21]. Any generalization across different ecosystems and environmental conditions is unwarranted, especially when comparing studies performed in very different conditions and different taxonomic levels. The environmental conditions of tropical highaltitude lakes are unique and differ much from the ones reported elsewhere in temperate and low-altitude freshwater ecosystems. It can be expected that the environmental vari- 
ables that matter for phytoplankton in tropical high-altitude conditions differ from those at other altitudes and latitudes.

We found no evidence of any relationship between geographic distance and community similarity. It is possible that the spatial structure of communities in Tres Lagunas is different at large spatial scales, where dispersal limitation may act more strongly. Perhaps at relatively small spatial scales like in this study $(<10 \mathrm{~km})$ high dispersal between local communities homogenizes the spatial structure of the communities and a higher impact of environmental conditions is observed. Microorganisms' biogeographical patterns probably emerge stronger at much larger spatial scales [31]. In line with our results, other previous studies with freshwater phytoplankton found no support for the distance-decay relationship in freshwater phytoplankton $[19,20,22]$. Importantly, this lack of support of the distance-decay relationship cannot be interpreted as unequivocal evidence for considering microorganisms having a global distribution. In this study, we estimated geographical distances as overland GPS (Global Positioning System)-based distances between lakes with different levels of water connectivity, belonging to two different drainage basins. It is possible that a higher spatial signal in community structure would be found if we had included water course distances or other determinants of dispersal capabilities in phytoplankton. However, connectivity patterns in Tres Lagunas would be hard to establish because páramos are wetlands where the soil is permanently soaked with water. The lack of a distance-related spatial structure in our study may also result from the sampling methods used. We sampled each lake only once at one depth. Thus, our dataset included only a snapshot of the transient community structure of phytoplankton in these lakes, without including within-lake or temporal variability. Single sampling may only represent a very small proportion of the real diversity of a lake [32]. We also acknowledge a possible methodological limitation of this study related to the use of relative abundances. An analysis based on total abundances of the different phyla could have been very informative in terms of the direction and magnitude in change in community composition among lakes.

Despite the observed relationships between environmental variables and community composition, a major proportion of among-lake community variation remained unexplained. Some possible explanations are that other important environmental variables were not included, that the spatial scale we used does not embrace the regional processes that matter for phytoplankton, that trophic effects such as grazing by zooplankton were not considered, and that the taxonomic resolution (i.e., phyla level) was too coarse. Phytoplankton includes a huge variety of life forms and it is possible that the environmental and spatial forces driving distribution patterns differ across the major phyla. Moreover, recent studies in similar tropical high-altitude lakes show that phytoplankton communities in these lakes are quite sensitive to human-driven alterations, such as eutrophication, temperature increase, and the introduction of fish [33-35]. Whereas tropical high-altitude lakes can also show some temporal variations in community composition the relatively stable environmental conditions of tropical páramos should result in limited seasonal variation in phytoplankton composition [26]. All the above-mentioned factors might contribute and interact with each other to determine the phytoplankton community composition in high-altitude tropical lakes.

\section{Conclusions}

Phytoplankton composition at the phyla level showed high among-lake variation in the tropical high-altitude lakes from Tres Lagunas. We found no links between the geographic distance and phytoplankton composition. On the contrary, we observed some environmentally related patterns of community structure, with highest dissimilarity among community structure at intermediate environmental distances. Spatial composition patterns based on field data alone like the ones reported here cannot be used to reveal the underlying mechanistic determinants of community assembly. Controlled experiments are required to depict the processes that generate those patterns. The absence of support for the distance-decay relationship observed here can result from a conjunction of local 
niche-based effects and dispersal limitations. Community composition in the Tres Lagunas system or any other ecosystem may be jointly regulated by niche-based and neutral forces that still need to be explored. More studies are required to determine their relative importance as drivers of community composition in unexplored systems such as the high-altitude tropical lakes.

Supplementary Materials: The following are available online at https:/ /www.mdpi.com/article/10 .3390/w13101378/s1, Table S1: Geographical coordinates, surface, altitude and maximum depth of the lakes included in this study.

Author Contributions: Conceptualization, A.C. and P.V.; investigation, A.C.; methodology, A.C. and P.V.; project administration, P.V.; resources, K.M.M.; supervision, B.W.I.; validation, K.M.M.; visualization, A.C.; writing—original draft, A.C.; writing—review and editing, A.C., K.M.M., B.W.I. and P.V. All authors have read and agreed to the published version of the manuscript.

Funding: This research was funded by the Swiss National Science Foundation (grant S18833) to Patrick Venail and by Senescyt (Ecuador) to Alonso Cartuche.

Institutional Review Board Statement: Not applicable.

Informed Consent Statement: Not applicable.

Data Availability Statement: Data included in this study will be available from the Dryad Digital Repository upon acceptance.

Acknowledgments: The authors would like to thank Nikolay Aguirre, his research group members at the Universidad Nacional de Loja (Loja, Ecuador), and the Secretaría del Agua of Ecuador for their support during the field campaign. We thank Fondation Schmidheiny for partially supporting Alonso Cartuche's PhD work. We are very grateful to the editors of the Special Issue of Water and three anonymous reviewers for the helpful suggestions.

Conflicts of Interest: The authors declare no conflict of interest.

\section{References}

1. Huston, M.A. Biological Diversity: The Coexistence of Species on Changing Landscapes; Cambridge University Press: Cambridge, UK, 1994; 681p.

2. Chesson, P. Mechanisms of maintenance of species diversity. Annu. Rev. Ecol. Syst. 2000, 31, 343-366. [CrossRef]

3. Wright, J.S. Plant diversity in tropical forests: A review of mechanisms of species coexistence. Oecologia 2002, 130, 1-14. [CrossRef]

4. Nekola, J.C.; White, P.S. The distance decay of similarity in biogeography and ecology. J. Biogeogr. 1999, 26, 867-878. [CrossRef]

5. Soininen, J.; McDonald, R.; Hillebrand, H. The distance decay of similarity in ecological communities. Ecography 2007, 30, 3-12. [CrossRef]

6. Leibold, M.A.; Holyoak, M.; Mouquet, N.; Amarasekare, P.; Chase, J.M.; Hoopes, M.F.; Holt, R.D.; Shurin, J.B.; Law, R.; Tilman, D.; et al. The metacommunity concept: A framework for multi-scale community ecology. Ecol. Lett. 2004, 7, 601-613. [CrossRef]

7. Hubbell, S.P. The Unified Neutral Theory of Biodiversity and Biogeography; Princeton University Press: Princeton, NJ, USA, 2001; 392p.

8. Cottenie, K. Integrating environmental and spatial processes in ecological community dynamics. Ecol. Lett. 2005, 8, 1175-1182. [CrossRef]

9. Thompson, R.; Townsend, C. A truce with neutral theory: Local deterministic factors, species traits and dispersal limitation together determine patterns of diversity in stream invertebrates. J. Anim. Ecol. 2006, 75, 476-484. [CrossRef]

10. De Wit, R.; Bouvier, T. 'Everything is everywhere, but, the environment selects'; what did Baas Becking and Beijerinck really say? Environ. Microbiol. 2006, 8, 755-758. [CrossRef] [PubMed]

11. Finlay, B.J.; Fenchel, T. Cosmopolitan metapopulations of free-living microbial eukaryotes. Protist 2004, 155, 237-244. [CrossRef] [PubMed]

12. Finlay, B.J. Global dispersal of free-living microbial eukaryote species. Science 2002, 296, 1061-1063. [CrossRef] [PubMed]

13. Green, J.L.; Holmes, A.J.; Westoby, M.; Oliver, I.; Briscoe, D.; Dangerfield, M.; Gillings, M.; Beattie, A.J. Spatial scaling of microbial eukaryote diversity. Nature 2004, 432, 747-750. [CrossRef] [PubMed]

14. Heino, J.; Bini, L.M.; Karjalainen, S.M.; Mykrä, H.; Soininen, J.; Vieira, L.C.G.; Diniz-Filho, J.A.F. Geographical patterns of micro-organismal community structure: Are diatoms ubiquitously distributed across boreal streams? Oikos 2010, 119, 129-137. [CrossRef]

15. Martiny, J.B.H.; Bohannan, B.J.M.; Brown, J.H.; Colwell, R.K.; Fuhram, J.A.; Green, J.L.; Horner-Devine, C.; Kane, M. Adams Krumins, J.; Ruske, C.R.; et al. Microbial biogeography: Putting microorganisms on the map. Nat. Rev. Microbiol. 2006, 4, 102-112. [CrossRef] [PubMed] 
16. Telford, R.J.; Vandvik, V.; Birks, H.J.B. Dispersal limitations matter for microbial morphospecies. Science 2006, 312, 1015. [CrossRef] [PubMed]

17. Whitaker, R.J.; Grogan, D.W.; Taylor, J.W. Geographic barriers isolate endemic populations of hyperthermophilic archaea. Science 2003, 301, 976-978. [CrossRef]

18. Astorga, A.; Oksanen, J.; Luoto, M.; Soininen, J.; Virtanen, R.; Muotka, T. Distance decay of similarity in freshwater communities: Do macro-and microorganisms follow the same rules? Glob. Ecol. Biogeogr. 2012, 21, 365-375. [CrossRef]

19. Mazaris, A.D.; Moustaka-Gouni, M.; Michaloudi, E.; Bobori, D.C. Biogeographical patterns of freshwater micro-and macroorganisms: A comparison between phytoplankton, zooplankton and fish in the eastern Mediterranean. J. Biogeogr. 2010, 37, 1341-1351. [CrossRef]

20. Goldenberg Vilar, A.; van Dam, H.; van Loon, E.E.; Vonk, J.A.; van Der Gest, H.G.; Admiraal, W. Eutrophication decreases distance decay of similarity in diatom communities. Freshw. Biol. 2014, 59, 1522-1531. [CrossRef]

21. Soininen, J.; Kokocinski, M.; Estlander, S.; Kotanen, J.; Heino, J. Neutrality, niches, and determinants of plankton metacommunity structure across boreal wetland ponds. Ecoscience 2007, 14, 146-154. [CrossRef]

22. Soininen, J.; Korhonen, J.J.; Karhu, J.; Vetterli, A. Disentangling the spatial patterns in community composition of prokaryotic and eukaryotic lake plankton. Limnol. Oceanogr. 2011, 56, 508-520. [CrossRef]

23. Wetzel, C.E.; Bicudo, D.C.; Ector, L.; Lobo, E.A.; Soininen, J.; Landeiro, V.L.; Bini, L.M. Distance decay of similarity in neotropical diatom communities. PLoS ONE 2012, 7, e45071. [CrossRef] [PubMed]

24. Pastorino, P.; Prearo, M. High-mountain lakes, indicators of global change: Ecological characterization and environmental pressures. Diversity 2020, 12, 260. [CrossRef]

25. Buytaert, W.; Célleri, R.; De Bièvre, B.; Cisneros, F.; Wyseure, G.; Deckers, J.; Hofstede, R. Human impact on the hydrology of the Andean páramos. Earth Sci. Rev. 2006, 79, 53-72. [CrossRef]

26. Van Colen, W.R.; Mosquera, P.V.; Vanderstukken, M.; Goiris, K.; Carrasco, M.-C.; Decaestecker, E.; Alonso, M.; León- Tamariz, F.; Muylaert, K. Limnology and trophic status of glacial lakes in the tropical Andes (Cajas National Park, Ecuador). Freshw. Biol. 2017, 62, 458-473. [CrossRef]

27. Cartuche, A.; Guan, Z.; Ibelings, B.W.; Venail, P. Phytoplankton diversity relates negatively with productivity in tropical high-altitude lakes from southern Ecuador. Sustainability 2019, 11, 5235. [CrossRef]

28. Hillebrand, H.; Dürselen, C.-D.; Kirschtel, D.; Pollingher, U.; Zohary, T. Biovolume calculation for pelagic and benthic microalgae. J. Phycol. 1999, 35, 403-424. [CrossRef]

29. Çelekli, A.; Öztürk, B.; Kapi, M. Relationship between phytoplankton composition and environmental variables in an artificial pond. Algal Res. 2014, 5, 37-41. [CrossRef]

30. Chen, X.; Bu, Z.; Stevenson, M.A.; Cao, Y.; Zeng, L.; Qin, B. Variations in diatom communities at genus and species levels in peatlands (central China) linked to microhabitats and environmental factors. Sci. Total Environ. 2016, 568, 137-146. [CrossRef]

31. Van der Gucht, K.; Cottenie, K.; Muylaert, K.; Vloemans, N.; Cousin, S.; Declerck, S.; Jeppesen, E.; Conde-Porcuna, J.-M.; Schwenk, K.; Zwart, G.; et al. The power of species sorting: Local factors drive bacterial community composition over a wide range of spatial scales. Proc. Natl. Acad. Sci. USA 2007, 104, 20404-20409. [CrossRef]

32. Korhonen, J.J.; Soininen, J.; Hillebrand, H. A quantitative analysis of temporal turnover in aquatic species assemblages across ecosystems. Ecology 2010, 91, 508-517. [CrossRef]

33. Barta, B.; Mouillet, C.; Espinosa, R.; Andino, P.; Jacobsen, D.; Christoffersen, K.S. Glacial-fed and páramo lake ecosystems in the tropical high Andes. Hydrobiologia 2018, 813, 19-32. [CrossRef]

34. Michelutti, N.; Wolfe, A.P.; Cooke, C.A.; Hobbs, W.O.; Vuille, M.; Smol, J.P. Climate change forces new ecological states in tropical Andean lakes. PLoS ONE 2015, 10, e0115338. [CrossRef] [PubMed]

35. Mouillet, C.; Barta, B.; Espinosa, R.; Andino, P.; Christoffersen, K.S.; Jacobsen, D. Ecological effects of introduced rainbow trout (Oncorhynchus mykiss) in pristine Ecuadorian high Andean lakes. Fundam. Appl. Limnol. 2018, 191, 323-337. [CrossRef] 